\title{
Circulating immune complexes in myasthenia gravis: a study in relation to thymectomy, clinical severity and thymus histology
}

\author{
CARLO BARTOLONI,* LUISA GUIDI,* CIRIACO SCOPPETTA, $\dagger$ \\ PIETRO TONALI, $\dagger$ EMANUELA BARTOCCIONI, $\ddagger$ GIOVANNA FLAMINI, \\ GINO GAMBASSI,* TULLIO TERRANOVA $\ddagger$
}

From the Istituto di Patologia Speciale Medica,${ }^{*}$ Istituto di Clinica Neurologica,$\uparrow$ and Istituto di Patologia Generale, $\ddagger$ Università Cattolica del Sacro Cuore, Rome, Italy

SUMMARY Circulating immune complexes were assayed employing the method recently described by Barnett and Chia in a group of patients with myasthenia gravis. The subjects were classified according to clinical severity and immune complexes were sought before and after thymectomy. The operated subjects were further divided into those with thymoma or thymic hyperplasia. Antigenantibody complexes were higher before thymectomy than after, in hyperplasias than in thymomas, and in severe myasthenia gravis than in mild disease. Circulating immune complexes and antiacetylcholine receptor antibodies did not correlate.

Myasthenia gravis (MG) is a disorder of neuromuscular transmission which is probably due to an autoimmune mechanism leading to reduction of the available nicotinic acetylcholine receptors (Ach-Rs) at the postsynaptic membrane of skeletal muscles. It is possible to induce experimental autoimmune myasthenia gravis employing purified Ach-R extracts (from Electrophorus electricus and Torpedo californica electric organs or from denervated mammalian muscle) in order to immunise NZW rabbits actively, which thereafter display a typical electrophysiological and clinical picture of myasthenia gravis. ${ }^{1}$ Other investigators, by means of passive immunisation have been able to reproduce experimental autoimmune myasthenia gravis by injecting aliquots of myasthenic patients' sera into the mouse. ${ }^{2}$ Drachman et $a l^{3}$ employing IgG purified fractions of myasthenia gravis subject sera, discovered that the binding of antibody from myasthenic patients alters the Ach- $R$ so that it could be preferentially degradated by the muscle cells. A serum globulin from myasthenia gravis patients is able to block the binding of alphabungarotoxin to the human neuromuscular junction,

Address for reprint requests: Dr Carlo Bartoloni, MD, Istituto di Patologia Speciale Medica, Università Cattolica del S. Cuore, Via della Pineta Sacchetti, 644 I-00168 Roma, Italy.

Accepted 1 July 1981 as shown on a morphological basis by Bender and to denervated rat muscle Ach-R. ${ }^{5}$ Also, electron microscope studies have demonstrated the presence of immune complexes of IgG and $\mathrm{C}_{3}$ at the motor end plate both in human and experimental autoimmune myasthenia gravis ${ }^{6-8}$

In man many attempts have been made to detect circulating antibodies directed against the Ach- $R$ protein and to establish a direct relation between their presence and the clinical evaluation of the myasthenic patient..$^{9-11}$ There is increasing evidence of an association between autoimmune diseases and myasthenia gravis, and that rheumatoid arthritis, ${ }^{12}$ thyroid disorders, ${ }^{13}$ idiopathic thrombocytopenic purpura, ${ }^{1415}$ and, perhaps, SLE ${ }^{16}$ occur more frequently. The possibility of a common pathogenesis of this neuromuscular disease and associated autoimmune conditions should be considered; the thymus could play a determining role $^{17}$ and evidence of hidden autoimmune disease should be sought in every myasthenic patient.

There are few reports of circulating immune complexes in myasthenia gravis in the literature. ${ }^{18-20}$ The possible presence of myasthenia gravis and immune complex-mediated disease in the same patient, and the suggested autoimmune pathogenesis of such a neuromuscular disorder, prompted us to assay immune complexes in the serum of several myasthenic patients in relation to clinical severity and thymus histology. The immune complex assay 
was performed before thymectomy and repeated at least one year after surgery.

\section{Materials and methods}

\section{Patients}

The myasthenic patients were classified according to clinical severity into mild (purely ocular and mild generalised) and severe (severe generalised with or without respiratory weakness) myasthenia gravis according to previously reported criteria. ${ }^{17}$ The operated subjects were further divided, according to thymus histology into thymomas and hyperplasias. Fifty-three subjects were studied before thymectomy. Forty-two out of 53 underwent operation and were divided histologically into thymic hyperplasias (34) or thymomas (8). Eleven patients were not treated surgically. Sixty blood samples were obtained from myasthenic patients one year or more after thymectomy. They were classified as $\mathbf{2 2}$ thymomas and 38 hyperplasias. Forty-two of these subjects had already been studied before the surgical approach and 18 of them underwent operation before we started the present study. None of the patients had autoimmune disease known to be associated with circulating antigen-antibody complexes. Every patient was included in the study concerning the assay of circulating IC in order to establish a possible relationship between clinical severity, thymic histology and response to surgical treatment (thymectomy). Twenty-one age-matched healthy blood bank donors were also simultaneously studied as a control group.

\section{Immune complex assay}

Blood samples were obtained by venipuncture and allowed to clot at room temperature; the serum was then frozen in $1 \mathrm{ml}$ aliquots at $-50^{\circ} \mathrm{C}$ until assayed. Serum immune complex levels were determined by the method recently described by Chia et al..$^{21}$ Each assay was run in triplicate; the serum sample $(0 \cdot 1 \mathrm{ml})$ was mixed with $0.1 \mathrm{ml}$ of $8 \%$ polyethyleneglycol (PEG) in phosphate buffered saline (0.01 M pH 7.4 PBS) and then incubated for $1 \mathrm{~h}$ at $4^{\circ} \mathrm{C}$. Mixtures were centrifuged at $1000 \mathrm{~g}$ for $1 \mathrm{~h}$ at $4{ }^{\circ} \mathrm{C}$ and the pellets were then washed with $0.5 \mathrm{ml}$ of $4 \%$ PEG. The washed pellets were resuspended in $0.1 \mathrm{ml}$ PBS by mechanical stirring until complete and permanent clearing of the solution. IgG level was measured by radial immunodiffusion (RID) according to Mancini ${ }^{22}$ both in the serum and in the resuspended pellet. The percentage of serum IgG precipitated by PEG was then calculated to compensate for the variability of the immunoglobulin in the serum; immune complex concentration, therefore, was expressed as per cent of $4 \%$ PEG-precipitable immunoglobulins G. All samples were run at once, control group included. Positive and known negative control sera were analysed to standardise the procedure. The normal value for circulating immune complexes obtained assaying their levels in the control group was $2 \cdot 27 \pm 0 \cdot 58$. The percentage of IgG precipitated by $4 \%$ PEG in excess of 2 standard deviations from the normal mean was considered to be immune complexes; a value exceeding $3.45 \%$, therefore, should be defined abnormal, as observed in those diseases known to be associated with immune complexes (vasculitis, R-A,
SLE, Behçet's syndrome) in agreement with previously reported data. ${ }^{21}$ Group means were compared by Student's $t$ test. Linear regression equation was employed to look for possible correlation between anti Ach-R antibody titre and immune complex levels (see under Results).

\section{Results}

The results obtained in the subjects studied before and after one year or more from thymectomy divided according to thymic histology and compared to controls, directly expressed as immune complex concentrations, are shown in tables 1 and 2. Actual IgG values $(\mathrm{mg} / 100 \mathrm{ml})$ were: thymoma $\mathrm{MG}: 1261 \pm$ 75.3 (serum), 59.8 \pm 3.37 (complexed) before thymectomy and 1522.4 $\pm 57 \cdot 8$ (serum), $55 \cdot 3 \pm 4$ (complexed) after the operation; hyperplasia myasthenia gravis: $1567.2 \pm 56.8$ (serum), $93.7 \pm$ $9 \cdot 1$ (complexed) before surgery and 1347.6 \pm 31 (serum), $76 \pm 4.7$ (complexed) after thymectomy. It should be emphasised that, for each patient, the calculation of immune complex concentration as per cent PEG-precipitable immunoglobulins $G$ was directly performed from a triplicate assay (both in the serum and in the resuspended pellet) and not from the actual IgG mean values representing the whole groups. Circulating immune complex levels were always higher in hyperplasias than in thymomas and, in almost all the studied groups, they displayed higher values before thymectomy than after, even if the patients were subgrouped in relation to clinical severity. In hyperplasia myasthenia gravis patients, although the decrease in immune complex concentration after the operation does reach a border line statistically significant level only, the general trend following thymectomy was confirmed. The unique group in which the immune complex levels were higher after thymectomy, when compared with their value before the operation, were those with mild myasthenia gravis, with thymoma, but this may be explained by the small number of patients. When the myasthenic patients were classified according to clinical severity, immune complexes were generally found to be significantly higher in the severe form of myasthenia gravis than in the mild one.

In the control population the mean concentration of antigen-antibody complexes was lower than in every myasthenic patient group; in the latter, anti Ach-R antibodies have been assayed as described elsewhere. ${ }^{11}$ No correlation was found between anti Ach-R antibody titre and circulating immune complex levels.

\section{Discussion}

Previous reports from other investigators have 
Table 1 Circulating immune complexes in myasthenia gravis patients

\begin{tabular}{|c|c|c|c|c|}
\hline & \multirow{2}{*}{$\begin{array}{l}\text { Patients } \\
\text { No }\end{array}$} & \multicolumn{2}{|c|}{$\%$ PEG-precipitable IgG } & \multirow{2}{*}{$\begin{array}{l}\text { Comparison between control and } \\
\text { MG patient group } \\
p \text { value }\end{array}$} \\
\hline & & Mean & $\pm S D$ & \\
\hline \multicolumn{5}{|l|}{ Before thymectomy } \\
\hline Thymoma MG (all) & 8 & $4 \cdot 33$ & $0 \cdot 232$ & $<0.001$ \\
\hline Hyperplasia MG (all) & 34 & 5.98 & 0.5 & $<0.001$ \\
\hline All MG & 53 & $5 \cdot 68$ & 0.468 & $<0.001$ \\
\hline Normal Subjects & 21 & $2 \cdot 27$ & $0 \cdot 58$ & - \\
\hline \multicolumn{5}{|l|}{ After thymectomy } \\
\hline Thymoma MG (all) & 22 & $3 \cdot 81$ & $0 \cdot 19$ & $<0.001$ \\
\hline Hyperplasia MG (all) & 38 & $5 \cdot 77$ & 0.39 & $<0.001$ \\
\hline All MG & 60 & 5.05 & 0.343 & $<0.001$ \\
\hline
\end{tabular}

Table 2 Comparison between IC levels in MG patient groups analysed by Student's t test

\begin{tabular}{lll}
\hline Before thymectomy & $p$ value & After thymectomy \\
\hline Mild MG < Severe MG & $<0.001$ & Mild MG $<$ Severe MG \\
Hyperplasia MG > Thymoma MG & $<0.001$ & Hyperplasia MG $>$ Thymoma MG \\
& & \\
IC levels compared before vs after thymectomy & & \\
MG before thymectomy $>$ MG after thymectomy & $<0.001$ \\
Mild MG before thymectomy > Mild MG after thymectomy & $<0.001$ \\
Severe MG before thymectomy > Severe MG after thymectomy & $<0.001$ \\
Hyperplasia MG before thymectomy > Hyperplasia MG after thymectomy \\
Thymoma MG before thymectomy > Thymoma MG after thymectomy
\end{tabular}

*Border line significant level.

emphasised the pathogenetic role of complement both in human and in experimental myasthenia gravis. The first investigations were made by Nastuk and associates more than 20 years ago;23-25 more recently, this view has been confirmed experimentally in passively induced myasthenia gravis by myasthenic serum in mice, ${ }^{2}$ and in experimental autoimmune myasthenia gravis which could not occur in complement depleted rats employing cobra venom factor. ${ }^{26}$ Immunoelectronmicroscopic studies have shown the presence of deposits of IgG and $\mathrm{C}_{3}$ at the postsynaptic membrane level of the motor endplates in myasthenia patients ${ }^{6}$ and in experimental autoimmune myasthenia gravis. ${ }^{7}$ These reports and the finding of anti Ach- $R$ antibodies in most of the myasthenia gravis patients ${ }^{9-11}$ and the good correlation between reduction of $\mathrm{C}_{4}$ and $\mathrm{C}_{1 \mathrm{q}}$-binding activity, which is an expression of circulating immune complexes, observed in seven of eight subjects with myasthenia gravis by Casali and associates, ${ }^{18}$ have prompted us to seek antigen-antibody complexes in the serum of our myasthenic patients. Although the published works on myasthenia gravis and circulating immune complexes are yet few, our data do not seem to be in agreement with the results obtained by Behan and Behan ${ }^{20}$ who reported a conspicuous association between decreased $\mathrm{C}_{4}$ concentrations (and presence of immune complexes) and mild or moderate disease; in addition, Tachovsky et al, 19 employing the Raji-cell radioimmune assay, found no serum circulating immune complex in five myasthenic patients, although by the use of a different method, the same kind of immune complex could not be detected. ${ }^{27}$

In myasthenic patients with thymoma we found lower values of circulating immune complexes than in those with hyperplasia, as also in those with severe myasthenia gravis when compared with those with mild disease. Evaluating the patients one year or more after the operation, a decrease in immune complex levels followed thymectomy but a difference persisted between hyperplasias and thymomas. In the light of previously reported data concerning anti Ach-R antibodies and cell-mediated immunity, ${ }^{29} 30$ the results we obtained seem to confirm that the immune system plays an important part in the pathogenesis of myasthenia gravis, although its complete role is not clear yet.

Our data indicate that, in myasthenia gravis, circulating immune complex levels are generally higher before thymectomy than after and they are always more elevated in thymic hyperplasias than in thymomas. This might reflect a different functional activity between hyperplastic and neoplastic thymic cells. In addition, immune complex levels appear to be higher in the severe form of myasthenia gravis 
than in the mild one, suggesting the possibility of a modulation of the antigenic stimulus and of the antibody responses in the different clinical forms of myasthenia gravis.

The concentration of anti Ach- $R$ antibodies decreased after surgical excision of the thymus ${ }^{10}$ and a positive correlation has been described between the severity of the disease and the amount of the receptor antibody. ${ }^{28}$ The level of circulating immune complex and the titre of anti Ach-R antibodies evaluated in our patient groups, however, did not correlate. This finding could mean that either the Ach- $R$ antibody assay is only able to recognise uncomplexed antibodies (excess of antibody) or, more likely, that the possible antigen involved in the immune complex formation represents immunologically active Ach- $R$ degradation products. These hypotheses are supported by Drachman's, ${ }^{3}$ Engel's ${ }^{6}$ and Sahashi's ${ }^{7}$ investigations but further studies are needed in order to evaluate the exact composition of circulating immune complexes detected in myasthenia gravis patients.

\section{References}

1 Penn AS, Chang HW, Lovelace RE et al. Antibodies to acetylcholine receptors in rabbits. Immunological and electrophysiological studies. Ann NY Aca Sci 1976;274:354-76.

2 Toyka KV, Drachman DB, Griffin DE et al. Myasthenia gravis: study of humoral immune mechanisms by passive transfer to mice. $N$ Engl J Med 1977;296: 125-34.

${ }^{3}$ Drachman DB, Angus CW, Adams RN et al. Effect of myasthenic patients' immunoglobulin on acetylcholine receptor turnover. Selectivity of degradation process. Pro Nat Aca Sci USA 1978;75(7):3422-6.

4 Bender AN, Ringel SP, Engel WK et al. Myasthenia gravis. A serum factor blocking acetylcholine receptor of the human neuromuscular junction. Lancet 1975;1:607-9.

5 Almon RR, Andrew CG, Appel SH. Serum globulin in myasthenia gravis. Inhibition of alfa bungarotoxin binding to acetylcholine receptors. Science 1974;186: 55-7.

${ }^{6}$ Engel AG, Lambert EH, Howard FM. Immune Complexes (IgG and $\mathrm{C}_{3}$ ) at the Motor End Plate in Myasthenia Gravis. Ultrastructural and Light Microscopic Localization and Electrophysiologic Correlations. Mayo Clin Proc 1977;52:267-80.

${ }^{7}$ Sahashi K, Engel AG, Lindstrom JM et al. Ultrastructural localization of immune complexes (IgG and $\mathrm{C}_{3}$ ) at the end plate in experimental autoimmune myasthenia gravis. J Neuropathol Exp Neurol 1978; 37:212-23.

${ }^{8}$ Engel AG, Lindstrom JM, Lambert EH et al. Ultrastructural localization of the acetylcholine receptor in myasthenia gravis and in its experimental autoimmune model. Neurology (Minneap) 1977;27:
307-15.

${ }^{9}$ Lindstrom JM, Seybold ME, Lennon VA et al. Antibody to acetylcholine receptor in myasthenia gravis. Prevalence, clinical correlates and diagnostic value. Neurology (Minneap) 1976;26:1054-9.

${ }^{10}$ Lefvert AK, Bergstrom K, Matell G et al. Determination of acetylcholine receptor antibody in myasthenia gravis: clinical usefulness and pathogenetic implication. J Neurol Neurosurg Psychiatry 1978; $41: 394-403$.

11 Bartoccioni E, Scuderi F, Scoppetta C et al. Myasthenia gravis, thymectomy and anti Ach-R antibody. $J$ Neurol 1980;224:9-15.

12 Oosterhuis HJGH, De Hass WHD. Rheumatic diseases in patients with myasthenia gravis. Acta Neurol Scand 1968;44:219-27.

${ }^{13}$ Rof-Carballo J. Myasthenia gravis and hyperthyroidism in neurology. Proceeding $X$ International Congress of Neurology. Excerpta Medica Congress Series 1975;319:446-59.

${ }^{14}$ Segal BM, Weintraub MI. Hashimoto's thyroiditis, myasthenia gravis, idiopathic thrombocytopenic purpura. Ann Intern Med 1976;85:761.

15 Veenhoven WA, Oosterhuis HJ, van der Schans GS. Myasthenia Gravis and Werlhof's Disease. Acto Med Scand 1979;206:131-5.

${ }^{16}$ Mizon JP, Morcamp D, Lefebvre P et al. Les associations myasthénie-lupus érythémateux disséminé. A propos de deux observations avec revue complète de la littérature. Ann Med Interne (Paris) 1979;11: 489-500.

${ }^{17}$ Scoppetta C, Tonali P, Evoli A et al. Treatment of Myasthenia Gravis. Report on 139 Patients. $J$ Neurol 1979;222:11-21.

${ }^{18}$ Casali P, Borzini P, Zanussi C. Immune complexes in Myasthenia gravis. Lancet 1976;2:378 (letter)

19 Tachovsky TG, Koprowski H, Lisak RP et al. Circulating immune complexes in multiple sclerosis and other neurological diseases. Lancet 1976;2:997-9.

${ }^{20}$ Behan WMH, Behan PO. Immune complexes in Myasthenia gravis. J Neurol Neurosurg Psychiatry 1979;42:595-9.

${ }^{21}$ Chia D, Barnett EV, Yamagata J et al. Quantitation and characterization of soluble immune complexes precipitated from sera by polyethylene glycol (PEG). Clin Exp Immunol 1979;37:399-407.

${ }^{22}$ Mancini G, Carbonara AO, Heremans JF. Immunochemical quantitation of antigens by single radial immunodiffusion. Immunochemistry 1965;2:235-54.

${ }^{23}$ Nastuk WL, Osserman KE, Plescia OJ. Reduction in serum complement concentration in myasthenia gravis. Fed Proc 1956;15:135-6.

${ }^{24}$ Nastuk WL, Plescia OJ, Osserman KE. Changes in serum complement activity in patients with myasthenia gravis. Proc Soc Exp Biol Med 1960;105:17784.

${ }^{25}$ Nastuk WL, Strauss AJL, Osserman KE. Search for a neuromuscular blocking agent in the blood of patients with myasthenia gravis. Am J Med 1959;26: 394-409.

${ }^{26}$ Lennon VA, Seybold ME, Lindstrom JM et al. Role of complement in the pathogenesis of experimental 
autoimmune myasthenia gravis. $J$ Exp Med 1978; 147:973-83.

27 Nydegger U, Kazatchkine M. Le détection du complexes immuns solubles. Nouv Presse Méd 1979; 8(3): $203-9$.

${ }^{28}$ Lefvert AK, Matell G. Antibodies against Human Cholinergic Receptor Proteins in Patients with Myasthenia Gravis. Studies during Immunosuppressive Treatment. Acta Med Scand 1977;201:
181-2.

${ }^{29}$ Abramsky O, Aharonov A, Webb C et al. Cellular immune response to acetylcholine receptor-rich fraction in patients with myasthenia gravis. Clin Exp Immunol 1975;19:11-6.

${ }^{30}$ Richman DP, Patrick J, Arnason BGW. Cellular immunity in myasthenia gravis. $N$ Engl J Med 1976; 294:694-8. 